\title{
A Steady-state Model for Prediction of Poinsettia Plant Shoot-tip Temperature
}

\author{
Hiroshi Shimizu \\ School of Agriculture, Ibaraki University, Ibaraki 300-0393, Japan \\ Erik S. Runkle ${ }^{1}$ and Royal D. Heins \\ Department of Horticulture, Michigan State University, East Lansing, MI 48824-1325
}

AdDITIONAL INDEX WORDS. convection, energy balance, longwave radiation, shortwave radiation, transpiration

\begin{abstract}
A model was constructed to predict shoot-tip temperature of poinsettia (Euphorbia pulcherrima Willd. ex Klotzsch) according to an energy-balance equation by using five greenhouse environmental factors: dry-bulb, wet-bulb, and sky (glazing or shade screen) temperature; transmitted shortwave radiation; and air velocity. An experiment was conducted to collect the five environmental variables that were used as model inputs, and shoot-tip temperature data were used to validate the predicted shoot-tip temperature in a commercial greenhouse. The standard deviation of the difference between predicted and measured shoot-tip temperature was 0.798 and was calculated by using 8547 data points, and $>84 \%$ of the actual and predicted data points were within $1{ }^{\circ} \mathrm{C}$. A sensitivity analysis performed with the model indicated that, among the three temperatures measured, plant shoot-tip temperature was primarily influenced by the dry-bulb temperature. For example, shoot-tip temperature increased an average of $0.74{ }^{\circ} \mathrm{C}$ for every $1^{\circ} \mathrm{C}$ increase in dry-bulb temperature when dry-bulb temperature varied from 28 to $42{ }^{\circ} \mathrm{C}$, wet-bulb temperature was $27.8{ }^{\circ} \mathrm{C}$, sky temperature was $39.8^{\circ} \mathrm{C}$, shortwave radiation $(285$ to $2800 \mathrm{~nm})$ was $760 \mathrm{~W} \cdot \mathrm{m}^{-2}$, and air velocity was $0.44 \mathrm{~m} \cdot \mathrm{s}^{-1}$. Under these conditions and a dry-bulb temperature of $32.6^{\circ} \mathrm{C}$, an increase in shortwave radiation of $500 \mathrm{~W} \cdot \mathrm{m}^{-2}$ increased the shoot-tip temperature by an average of $3.3^{\circ} \mathrm{C}$. This developed model may be a useful tool to predict shoot-tip temperature and evaluate the effect of greenhouse environmental factors on shoot-tip temperature.
\end{abstract}

The rate of plant development must be understood and controlled to manage production of ornamental crops to meet predetermined market finish dates. Many studies have found that apical meristem temperature, or shoot-tip temperature, is the primary factor that controls the rate of plant development (Ben-Haj-Salah and Tardieu, 1995; Faust and Heins, 1998; Gallagher and Biscoe, 1979; Gregory, 1983; Kempkes et al., 2000; Marcelis and de Koning, 1995; Ong, 1983; Tardieu et al., 2000; Wilhelm et al., 1989).

Plant shoot-tip temperature is often different from air temperature. For example, shoot-tip temperature of Catharanthus roseus $\mathrm{L}$. (vinca) grown at $15^{\circ} \mathrm{C}$ was equal to the dry-bulb greenhouse air temperature for only brief periods during the morning and late afternoon and was almost always 4 to $6{ }^{\circ} \mathrm{C}$ lower when plants were grown at a $35^{\circ} \mathrm{C}$ air temperature (Faust and Heins, 1998). Although shoot-tip temperature is seldom equal to air temperature, greenhouse climate control systems generally target air temperature, not plant temperature (Albright, 1990; Boulard and Draoui, 1996; Hanan, 1998; Nishina et al., 1996; Van Stranten and Challa, 1995). However, measurement of shoot-tip temperature in a commercial greenhouse is difficult. The development of a model that predicted shoot-tip temperature based on easily measured environmental factors could improve the accuracy and management of scheduling production of ornamental crops.

Poinsettia is the most valuable potted flowering plant in the United States, with wholesale sales > \$256 million in 2001 (United States Department of Agriculture, 2002). A typical production time from start of propagation to sale for poinsettia (which varies

Received for publication 25 Apr. 2003. Accepted for publication 19 Nov. 2003. We thank Natural Beauty Greenhouses for use of their greenhouses and support from the Michigan Agricultural Experiment Station. The authors would like to acknowledge the two anonymous reviewers for their detailed, constructive comments and suggestions.

'Corresponding author; e-mail runkleer@msu.edu. by container size, cultivar, and environmental conditions) is $\approx 16$ to 17 weeks (Dole and Wilkins, 1999). Freedom poinsettia has a calculated base temperature of $5.6^{\circ} \mathrm{C}$ (e.g., the rate of development is zero at or below $5.6^{\circ} \mathrm{C}$ ) and requires 65.5 degree days for one leaf to develop (unpublished data). Thus, if dry bulb temperature was $21^{\circ} \mathrm{C}$ but actual plant shoot-tip temperature was $20^{\circ} \mathrm{C}$, the rate of plant development would be $\approx 6.5 \%$ slower than that expected at the dry bulb temperature. If maintained throughout the entire life of the crop, this $1{ }^{\circ} \mathrm{C}$ deviation from flower initiation to marketing could translate into a delay of $\approx 3$ to $4 \mathrm{~d}$.

The goal of this project is to improve the prediction accuracy of growth and development of poinsettia. The specific objectives of this paper were 1) to construct an accurate model of plant shoot-tip temperature by using environmental factors that are commonly or easily measured in commercial greenhouses, and 2) to evaluate the effect of greenhouse environmental factors on shoot-tip temperature.

\section{Materials and Methods}

GreENhouse CONDitions. Plants were grown for data collection and model development in a commercial glass greenhouse in Apopka, Fla. (lat. $28^{\circ} \mathrm{N}$ ), from July to August 1998. One-half of the greenhouse was shaded with whitewash to reduce light transmission by $\approx 50 \%$, and the other half remained clear. The greenhouse was $\approx 36.5 \mathrm{~m}$ long and was cooled with a fog and fan system that operated when the greenhouse air temperature was $>26^{\circ} \mathrm{C}$. Environmental data were collected in one bay under the whitewashed glass and in one bay under clear glass.

In addition to whitewash, a retractable shade curtain (reducing light by $85 \%$ ) was installed, and deployment and retraction were primarily controlled by an environmental computer (QCOMCorp., Irvine, Calif.). Curtains were extended if all of these criteria were met: outdoor light intensity $>1200 \mu \mathrm{mol} \cdot \mathrm{m}^{-2} \cdot \mathrm{s}^{-1}$, indoor dry-bulb temperature $>40.5^{\circ} \mathrm{C}$, and time between 1100 and $1800 \mathrm{HR}$. Thus, 
four light environments were obtained by combining clear glass, whitewash, and the shading screen. However, the shade curtain was occasionally pulled at growers' discretion even when the above criteria were not met.

In each bay, dry-bulb and wet-bulb temperature were measured by thermocouples located at $\approx 9-\mathrm{m}$ intervals down the length of the greenhouse, for a total of 20 thermocouples per bay. Shoottip temperatures [measured by a type E thermocouple (TT-E-40, Omega Engineering Inc., Stamford, Conn.) inserted $\approx 0.5 \mathrm{~cm}$ below the shoot apex] from five 'Freedom Red' poinsettia plants located halfway down the length of the greenhouse were measured and recorded. At the same location, four infrared (IR, 6,000 to 14,000 $\mathrm{nm}$ ) transducers (Standard Infra-red Thermocouple Transducer; IRTS, Apogee Instruments, Inc., Logan, Utah) located $1.8 \mathrm{~m}$ from the floor were used to measure sky temperature (pointing upward) and plant canopy temperature (pointing downward). Sky temperature represented the greenhouse superstructure and glass when the curtain was retracted, and it represented the shading screen temperature when the screen was extended over the crop. A total hemispherical radiometer (model THRD55; Radiation and Energy Balance Systems, Inc., Seattle, Wash.) and two linequantum sensors (self-produced by using photodiode G2711-01; Hamamatsu Photonics Inc., Hamamatsu, Japan) were located near the IR transducers to measure net radiation and photosynthetic photon flux (PPF), respectively. Shortwave radiation was calculated from measured PPF and conversion factors (Thimijan and Heins, 1983). An air velocity transducer (model 8475; TSI, Inc., St. Paul, Minn.) located $.1 \mathrm{~m}$ above the canopy measured air velocity. A quantum sensor (LI-189; LI-COR, Inc., Lincoln, Neb.) and an Epply pyranometer (model PSP; Epply Laboratory, Inc., Newport, R.I.) were located on the roof of the greenhouse to measure outdoor PPF and shortwave radiation, respectively.

All data were collected every $10 \mathrm{~s}$ and averaged and recorded every $10 \mathrm{~min}$ by three data loggers (CR-10X; Campbell Scientific, Logan, Utah) that were connected to computers.

\section{Model Development}

ENERGY BALANCE. The balance of total incoming and outgoing energy determines plant shoot-tip temperature. If incoming energy exceeds outgoing energy, plant temperature increases until equilibrium is achieved. This relationship can be described by (Monteith and Unsworth, 1990) (Table 1)

$S W+L W+\operatorname{Con} w-\lambda E=0 \quad\left(\mathrm{~W} \cdot \mathrm{m}^{-2}\right)$

Shortwave Radiation. Eq. [2] was defined to calculate shortwave radiation absorbed by a plant shoot tip:

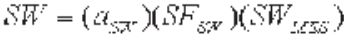
$\left(\mathrm{W} \cdot \mathrm{m}^{-2}\right)$

where $a_{S W}=0.34$, deciduous broad leaves under low sun; 0.88, conifers; and 0.50 , typical mean values for total shortwave (Jones, 1994), which was adopted in the model. Shape factor value depends on the shape and solar height; sometimes it is close to zero and sometimes $>1$ for shortwave radiation, and $S W_{M E S}$ is measured on a horizontal plane inside a greenhouse. The shape factor is the ratio of surface area exposed to direct solar radiation to the total surface area. We developed Eq. [3] to calculate that factor in this project:

$$
S H_{S F Y^{\prime}}=\frac{\pi d 1+\begin{array}{c}
d 2_{R .4 D} \\
\tan (j
\end{array}}{\left(\frac{d 1}{4}+d 2_{\mathbb{R} 4 L}\right) \pi}
$$

Solar altitude $(\theta)$ is calculated as (Kreith and Kreider, 1978)

$$
\theta=\sin ^{-1}\{\sin (\text { Lat }) \sin (\operatorname{SolDeC})+\cos (\text { Lat }) \cos (\operatorname{SolDeC}) \cos (\mathrm{Hr} A n g)
$$

(deg.) [4]

Solar declination and hour angle are calculated by (Kreith and Kreider, 1978)

$$
\begin{aligned}
& \text { SolDec }=(-23.4) \cos [2 \pi(D a y+10) / 365] \quad \text { (deg.) } \\
& \text { IIrAng }=(15)(\text { Hoty }-\operatorname{SolAzi}) \quad \text { (deg.) }
\end{aligned}
$$

LONGWAVE RAdiation. Plants placed on benches or the floor can be assumed to form a large plane with the same area as the greenhouse ceiling. Longwave radiation exchange between plants and ceiling is given as (Holman, 1997)

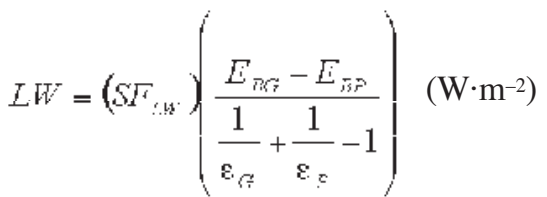

where $\frac{1}{\varepsilon_{g}}+\frac{1}{\varepsilon_{\eta}}-1$

is resistance for longwave radiation. In this project, we developed the following equation to define the shape factor for longwave radiation:

$S]_{L W}=\frac{d 1}{d 1+4 d 2_{\text {ros }}}$

where $\mathrm{d} 1$ and $\mathrm{d} 2$ are diameter and height of plant shoot-tip.

Convection. The method of convection has to be determined by calculating energy exchange caused by convection (Pitts, 1977):

Tree Compection : $\mathrm{Gr}>\mathrm{Re}^{\mathrm{i}}$

Forced Convection : $G r<\mathrm{Re}^{3}$

These numbers are defined as

$(r)=\frac{a g d^{3}\left|T_{D}-T_{P M P S}\right|}{v^{2}}$

$\operatorname{Re}=\frac{V d}{v}$

where $a=$ the inverse of temperature $T, 1 / \mathrm{T}$. In this research, the characteristic dimension of the plant shoot tip was described by (Pitts, 1977)

$d=\left(\frac{1}{d 1}+\frac{1}{d 2_{\text {i ON }}}\right)^{-1} \quad(\mathrm{~m})$

The total energy exchange by convection is given by

$C O m=h\left(T_{T}-T_{F W h S}\right) \quad\left(\mathrm{W} \cdot \mathrm{m}^{-2}\right)$

Free convection. Free convection is classified into laminar flow and turbulent flow (Holman, 1997) by

Laminar flow: $10^{4}<(G r)(\mathrm{Pr})<10^{\circ} \rightarrow h=(1.42)\left(\frac{\left|T_{D}-T_{\text {PAES }}\right|}{d}\right)^{4}$
Turbulent flow: $10^{\circ}<(G r)(\mathrm{Pr}) \rightarrow h=(1.31)\left(T_{D}-T_{\text {PSES }} \mid\right)^{3}$

$\left(\mathrm{W} \cdot \mathrm{m}^{-2} \cdot \mathrm{K}^{-1}\right)$

[14]

ForCed CONVECTION. Forced convection across a cylinder is expressed as (Holman, 1997)

$h=\left(\frac{\kappa}{d}\right)(c)\left(\frac{V d}{v}\right)^{n}\left(\mathrm{l}^{3} \mathrm{r}\right)^{1 / 3}\left(\mathrm{~W} \cdot \mathrm{m}^{-2} \cdot \mathrm{K}^{-1}\right)$ 
where $c$ and $n$ are constants that depend on the Reynolds number shown in Table 2 (Holman, 1997).

Transpiration. The total resistance for transpiration through the surface of a shoot tip is the combined resistance caused by the boundary layer and the cuticle (Jones, 1994). Thus, transpiration is written as (Monteith and Unsworth, 1990)

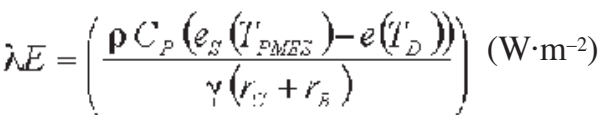

It has been shown theoretically in the field of heat transfer that the boundary layer resistance of water vapor $\left(r_{B}\right)$ is 0.93 times that of heat (Bejan, 1984).

Therefore, $\mathrm{r}_{\mathrm{B}}$ can be calculated as

$r_{B 3}=(0.93) \frac{p C_{p}^{-\gamma}}{h}\left(\mathrm{~s} \cdot \mathrm{m}^{-1}\right)$

The cuticle resistance of the shoot tip in poinsettia was reported as $960 \mathrm{~s} \cdot \mathrm{m}^{-1}$ (Shimizu and Heins, 2000), and this value was applied in the simulation.

Calculation Procedure EXample. This model can predict plant shoot-tip temperature by using the following five greenhouse environmental factors: dry-bulb, wet-bulb, and sky temperature; transmitted shortwave radiation; and air velocity. The calculations also require the following inputs: plant shoot-tip diameter, absorptivity of shortwave radiation by the plant shoot tip, emissivity of the sky material and plant shoot tip, latitude of the greenhouse location, date, and time.

The calculation procedure is demonstrated by using the hypothetical environmental conditions shown in Table 3 (calculation data). The developed model is categorized as a nonlinear function of $\mathrm{T}_{\mathrm{PMES}}$, and it is not analytically solved. Thus, a numerical calculation has to be employed to find the value of $\mathrm{T}_{\text {PMES }}$ that satisfies Eq. [1]. First, we use $T_{\text {PMES }}=30$ and calculate the energy balance, as follows.

1) Shortwave radiation $(\mathrm{SW})$

Solar altitude $(\theta)$ is calculated with Eqs. [4], [5], and [6]:

$$
\begin{aligned}
& \text { SolDec }=(-23.4)\{\cos [2 \pi(191+10) / 365](\text { deg. }) \\
& =22.2 \\
& \begin{aligned}
\text { HrAng } & =(15)(10.0-13.5)(\text { deg. }) \\
& =-52.5
\end{aligned} \\
& \begin{aligned}
\theta & =\sin ^{-1}\{\sin (28) \sin (22.2)+\cos (28) \cos (22.2) \cos (-52.5)\} \\
= & 42.5 \text { (deg.) }
\end{aligned}
\end{aligned}
$$

From d1 $(=0.006$, which was the mean of eight measurements using a digital caliper $)$ and $\mathrm{d} 2_{\mathrm{RAD}}(=0.002$, which was empirically determined using repeated calculations), $\mathrm{SF}_{\mathrm{SW}}$ is given by Eq. [3]:

$$
S F_{6 \pi}=\frac{\frac{\pi}{4} 0.006+\frac{0.002}{\tan (42.5)}}{\left(\frac{0.006}{4}+0.002\right) \pi}
$$$$
=0.63
$$

Eq. [13]

Thus, when incident $\mathrm{SW}$ is $600 \mathrm{~W} \cdot \mathrm{m}^{-2}$, Eq. [2] gives absorbed shortwave radiation:

$$
S W=(0.5)(0.63)(600)=189 \quad\left(\mathrm{~W} \cdot \mathrm{m}^{-2}\right)
$$

\section{2) Longwave radiation ( $\mathrm{LW})$}

Emissive power of a black body $\left(\mathrm{E}_{\mathrm{B}}\right)$ is given as

$E_{b}=\sigma T^{4}\left(\mathrm{~W} \cdot \mathrm{m}^{-2}\right)$

Thus,

$$
\begin{aligned}
& E_{B G}=(5.67 E-8)(26+273.15)^{4}=454.1 \\
& E_{B P}=(5.67 E-8)(30+273.15)^{4}=478.9
\end{aligned}
$$

By using Eq. [3], shape factor and resistance for longwave radiation are

$$
\begin{aligned}
S Y_{Z W} & =\frac{0.01}{0.01+(4)(0.002)} \\
& =0.43 \\
1+\varepsilon_{\square}-1 & =\frac{1}{0.94}+0.96 \\
& =1.1
\end{aligned}
$$

Thus, using Eq. [7], longwave radiation is

$$
L W=(0.43)\left(\frac{454.1-478.9}{1.1}\right)=-9.7\left(\mathrm{~W} \cdot \mathrm{m}^{-2}\right)
$$

\section{3) Convection}

Thermal expansion rate of air (a) and the kinematic viscosity of the air $(v)$ are $3.35 \mathrm{E}-3$ and $1.6 \mathrm{E}-5\left(\mathrm{~m}^{2} \cdot \mathrm{s}^{-1}\right)$ at $\mathrm{T}_{\mathrm{D}}$, respectively, and the acceleration of gravity $(g)$ is $9.8 \mathrm{~m} \cdot \mathrm{s}^{-2}$. In this study, $\mathrm{d} 2_{\mathrm{CONV}}$ was empirically determined and was the same as d1. Thus, the characteristic dimension of the shoot tip is given by Eq. [12] as $d=\left(\frac{1}{0.006}+\frac{1}{0.01}\right)^{-1}=0.0037(\mathrm{~m})$

The Grashof number and Reynolds number are, by Eqs. [10] and [11]

$$
\begin{aligned}
& G r=\frac{(3.35 E-3)(9.8)(0.0037)^{3}|25-30|}{(1.6 E-5)^{2}}=32.5 \\
& \operatorname{Re}=\frac{(0.2)(0.0037)}{1.6 E-5}=46.3 \\
& \operatorname{Re}^{2}=2139
\end{aligned}
$$

Since $\mathrm{Gr}<\mathrm{Re}^{2}$, convection is thus forced convection, using the relation in Eq. [9].

According to Holman (1997), the average heat-transfer coefficients in cross flow cannot be calculated analytically because of the complicated nature of the flow separation process. Thus, from Table $2, c=0.683$ and $n=0.466$. The thermal conductivity of the air ( $\kappa)$, Prandtle number (Pr), and kinematic viscosity of $\operatorname{air}(\boldsymbol{v})$ are $2.48 \mathrm{E}-2,0.71$ and $1.6 \mathrm{E}-5$, respectively. Substituting these values in Eq. [15],

$h=\left(\frac{2.48 E-2}{0.0037}\right)(0.683)\left(\frac{(0.2)(0.0037)}{1.6 E-5}\right)^{0.466} \begin{gathered}(0.71)^{1 / 3}=24.4 \\ \left(\mathrm{~W} \cdot \mathrm{m}^{-2} \cdot \mathrm{K}^{-1}\right)\end{gathered}$

Eq. [13] then gives

Conv $=(24.4)(25-30)=-122\left(\mathrm{~W} \cdot \mathrm{m}^{-2}\right)$

\section{4) Transpiration}

The constants used in transpiration at a mean temperature 
Table 1. List of abbreviations and parameters.

\begin{tabular}{|c|c|c|}
\hline Symbol & Description & Unit \\
\hline$\gamma$ & Psychrometer constant $(0.0663)$ & $\mathrm{kPa} \cdot \mathrm{K}^{-1}$ \\
\hline$\theta$ & Solar altitude & Degree \\
\hline$\lambda \mathrm{E}$ & Transpiration & $\mathrm{W} \cdot \mathrm{m}^{-2}$ \\
\hline$\kappa$ & Thermal conductivity of air & $\mathrm{W} \cdot \mathrm{m}^{-2} \cdot \mathrm{K}^{-1}$ \\
\hline$\rho$ & Density of air & $\mathrm{Kg} \cdot \mathrm{m}^{-3}$ \\
\hline$\sigma$ & Stefan-Boltzman constant (5.67E-8) & $\mathrm{W} \cdot \mathrm{m}^{-2} \cdot \mathrm{K}^{-4}$ \\
\hline$\varepsilon_{G}$ & Glazing material emissivity & \\
\hline$\varepsilon_{P}$ & Plant shoot tip emissivity & \\
\hline$a$ & Coefficient of thermal expansion rate of air & $\mathrm{K}^{-1}$ \\
\hline$a_{S W}$ & Plant shoot-tip absorptivity & \\
\hline Conv & Convection & $\mathrm{W} \cdot \mathrm{m}^{-2}$ \\
\hline$C_{P}$ & Specific heat of air & $\mathrm{J} \cdot \mathrm{kg}^{-1} \cdot \mathrm{K}^{-1}$ \\
\hline d & Plant shoot-tip characteristic dimension & $\mathrm{m}$ \\
\hline$d 1$ & Plant shoot-tip diameter & $\mathrm{m}$ \\
\hline$d 2_{\text {CONV }}$ & Plant shoot-tip height for calculating convection & $\mathrm{m}$ \\
\hline$d 2_{R A D}$ & Plant shoot-tip height for calculating radiation & $\mathrm{m}$ \\
\hline Day & Julian day number & \\
\hline$e\left(T_{D}\right)$ & Vapor pressure at $T_{D}$ & $\mathrm{kPa}$ \\
\hline$e_{S}\left(T_{P M E S}\right)$ & Saturation vapor pressure at $T_{P M E S}$ & $\mathrm{kPa}$ \\
\hline$E_{B}$ & Emissive power of a black body & $\mathrm{W} \cdot \mathrm{m}^{-2}$ \\
\hline$E_{B G}$ & Emissive power of a black body at glazing temperature & $\mathrm{W} \cdot \mathrm{m}^{-2}$ \\
\hline$E_{B P}$ & Emissive power of a black body at plant shoot-tip temperature & $\mathrm{W} \cdot \mathrm{m}^{-2}$ \\
\hline$g$ & Acceleration of gravity $(9.8)$ & $\mathrm{m} \cdot \mathrm{s}^{-2}$ \\
\hline$G r$ & Grashof number & \\
\hline$h$ & Convection heat-transfer coefficient & $\mathrm{W} \cdot \mathrm{m}^{-2} \cdot \mathrm{K}^{-1}$ \\
\hline Hour & Actual hour of day & \\
\hline HrAng & Hour angle & Degree \\
\hline Lat & Greenhouse location latitude & Degree \\
\hline$L W$ & Long-wave radiation & $\mathrm{W} \cdot \mathrm{m}^{-2}$ \\
\hline $\operatorname{Pr}$ & Prandtle number & \\
\hline$r_{B}$ & Boundary layer resistance for mass transfer & $\mathrm{s} \cdot \mathrm{m}^{-1}$ \\
\hline$r_{C}$ & Cuticle resistance of plant shoot tip & $\mathrm{s} \cdot \mathrm{m}^{-1}$ \\
\hline $\operatorname{Re}$ & Reynolds number & \\
\hline$S F_{L W}$ & Shape factor for long-wave radiation & \\
\hline$S F_{S W}$ & Shape factor for short-wave radiation; ratio of projective shade area on horizontal plane to total surface area & \\
\hline SolAzi & Solar noon & \\
\hline SolDec & Solar declination & Degree \\
\hline$S W$ & Short-wave radiation absorbed by plant shoot tip & $\mathrm{W} \cdot \mathrm{m}^{-2}$ \\
\hline$S W_{M E S}$ & Measured short-wave radiation & $\mathrm{W} \cdot \mathrm{m}^{-2}$ \\
\hline$T$ & Temperature & oK \\
\hline$T_{D}$ & Dry bulb temperature & ${ }^{\circ} \mathrm{C}$ \\
\hline$T_{P M E S}$ & Measured plant shoot-tip temperature & ${ }^{\circ} \mathrm{C}$ \\
\hline$T_{P S I M}$ & Simulated plant shoot-tip temperature & ${ }^{\circ} \mathrm{C}$ \\
\hline$T_{S}$ & Sky (glazing and superstructure or shade curtain) temperature & ${ }^{\circ} \mathrm{C}$ \\
\hline$T_{W}$ & Wetbulb temperature & ${ }^{\circ} \mathrm{C}$ \\
\hline$v$ & Kinematic viscosity of air & $\mathrm{m}^{2} \cdot \mathrm{s}^{-1}$ \\
\hline$V$ & Air velocity & $\mathrm{m} \cdot \mathrm{s}^{-1}$ \\
\hline
\end{tabular}

Table 2. Constants for use with Eq. [15].

\begin{tabular}{llc}
\hline $\mathrm{Re}^{\mathrm{z}}$ & $\mathrm{C}$ & $\mathrm{N}$ \\
\hline $0.4-4$ & 0.989 & 0.330 \\
$4-40$ & 0.911 & 0.385 \\
$40-4,000$ & 0.683 & 0.466 \\
$4,000-40,000$ & 0.193 & 0.618 \\
$40,000-400,000$ & 0.0266 & 0.805
\end{tabular}

${ }^{\mathrm{z}} \mathrm{Re}=$ Reynolds number. 
of $\left(T_{L}+\eta_{P: 4 i \leq s}^{\prime}\right) / 2$ are

$\rho=1.187 \quad\left(\mathrm{~kg} \cdot \mathrm{m}^{-3}\right)$

$C_{p}=1010 \quad\left(\mathrm{~J}^{\mathrm{kg}} \mathrm{kg}^{-1} \cdot \mathrm{K}^{-1}\right)$

$\gamma=0.0663 \quad\left(\mathrm{kPa} \cdot \mathrm{K}^{-1}\right)$

Ihe vapor pressure values are calculated with $\mathrm{T}_{\mathrm{D}}$ and $\mathrm{T}_{\mathrm{W}}$ :

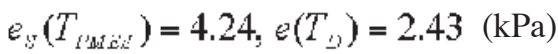

The value of cuticle resistance $\left(\mathrm{r}_{\mathrm{C}}\right)$ was taken from Shimizu and Heins (2000):

$r_{i:}=960 \quad\left(\mathrm{~s} \cdot \mathrm{m}^{-1}\right)$

The boundary resistance is given by Eq. [17]:

$r_{\varepsilon}=(0.93)\left(\frac{(1.187)(1010)}{24.4}\right)=45.7\left(\mathrm{~s} \cdot \mathrm{m}^{-1}\right)$

Thus, energy loss by transpiration is given by Eq. [16]:

$\lambda_{E}=\frac{(1.187)(1010)(4.24-2.43)}{(0.0663)(960+45.7)}=32.5 \quad\left(\mathrm{~W} \cdot \mathrm{m}^{-2}\right)$

Then the energy balance is, by Eq. [1],

$$
\begin{aligned}
S W+L W+C o n v-\lambda E & =189-9.7-122-32.5\left(\mathrm{~W} \cdot \mathrm{m}^{-2}\right) \\
& =24.8
\end{aligned}
$$

The total energy balance is $24.8\left(\mathrm{~W} \cdot \mathrm{m}^{-2}\right)$ at $\mathrm{T}_{\mathrm{PMES}}=30{ }^{\circ} \mathrm{C}$, which means incoming energy is more than outgoing energy at the assumed shoot-tip temperature. Therefore, the true $\mathrm{T}_{\mathrm{PMES}}$ that achieves a balanced Eq. [1] is greater than $30{ }^{\circ} \mathrm{C}$. If the assumed $\mathrm{T}_{\mathrm{PMES}}$ is $35^{\circ} \mathrm{C}$, the calculated energy balance is -80.5 . Thus, from these calculations, the true $\mathrm{T}_{\text {PMES }}$ must be between 30 and $35^{\circ} \mathrm{C}$.

\section{Results and Discussion}

Greenhouse EnVironment. One set of collected data (6 July 1998) under the clear glass is shown in Fig. 1. Sunrise was at $0640 \mathrm{HR}$, and solar radiation increased as the solar altitude in-

Table 3. Environmental characteristics used to demonstrate the model calculation procedure and the predicted effect of changing a single environmental factor on shoot-tip temperature. Data used for the calculation procedure are hypothetical. Data used for simulating the effect of changing an environmental factor are actual values (Fig. 4).

\begin{tabular}{lcc}
\hline & \multicolumn{2}{c}{ Model } \\
\cline { 2 - 3 } Factor & Calculation & Simulation \\
\hline $\mathrm{T}_{\mathrm{D}}$ (dry-bulb temperature) & 25 & 32.6 \\
$\mathrm{~T}_{\mathrm{W}}$ (wet-bulb temperature) & 22 & 27.8 \\
$\mathrm{~T}_{\mathrm{S}}$ (sky temperature) & 26 & 39.8 \\
$\mathrm{SW}_{\mathrm{MES}}$ (measured SW) & 600 & 760 \\
$\mathrm{~V}$ (air velocity) & 0.2 & 0.44 \\
$\mathrm{~d} 1$ (plant shoot-tip diameter) & 0.006 & 0.006 \\
$\mathrm{~A}_{\mathrm{SW}}$ (plant shoot-tip absorptivity) & 0.5 & 0.5 \\
$\mathrm{E}_{\mathrm{BG}}$ (Sky emissivity) & 0.94 & 0.94 \\
$\mathrm{E}_{\mathrm{BP}}$ (Plant shoot-tip emissivity) & 0.96 & 0.96 \\
Latitude (greenhouse location) & 28 & 28.4 \\
Date & $10 \mathrm{July}$ & $10 \mathrm{July}$ \\
Time & $1000 \mathrm{HR}$ & $1250 \mathrm{HR}$ \\
Culmination time & $1330 \mathrm{HR}$ &
\end{tabular}

${ }^{\mathrm{z}} \mathrm{SW}=$ shortwave radiation $(285-2800 \mathrm{~nm})$. creased until a maximum near 1300 HR, after which it dropped as a result of cloud cover around 1345 HR. Clouds completely obstructed direct solar radiation from $1620 \mathrm{HR}$ to sunset. The line-quantum sensor installed above the plant canopy shows that the shading screen was pulled twice, at 1230 to $1340 \mathrm{HR}$ and at 1410 to $1500 \mathrm{HR}$. Sky temperature increased from 45 to $55^{\circ} \mathrm{C}$ when the shading screen was extended over the crop at $1210 \mathrm{HR}$. Dry-bulb temperature started to increase at sunrise and continued to increase until it was almost $35^{\circ} \mathrm{C}$ in the afternoon. Wet-bulb temperature was generally stable at $\approx 25{ }^{\circ} \mathrm{C}$ the entire day. Air velocity varied from 0.2 to $0.6 \mathrm{~m} \cdot \mathrm{s}^{-1}$.

Shoot-tip Temperature Prediction. Predicted shoot-tip temperatures were validated by comparing predicted with measured data. Typical time-series data sets under the different light conditions are shown in Fig. 2. Figure 2A shows the actual and simulated shoot-tip temperatures under the clear glass. Measured and predicted temperatures were in close agreement during most of the day. The model overpredicted (by $<2.3{ }^{\circ} \mathrm{C}$ ) shoot-tip temperature for about the first $2 \mathrm{~h}$ of the morning, but during the middle of the day when the measured shoot-tip temperature was $\approx 5^{\circ} \mathrm{C}$ higher than dry-bulb temperature, the model predicted the same temperature as measured.

A comparison under the clear glass but with the shading screen is shown in Fig. 2B. The shading screen was pulled from 1230 to $1340 \mathrm{HR}$ and 1410 to $1500 \mathrm{HR}$, and measured and predicted temperatures dropped to the same level as dry-bulb temperature. The predicted temperature was $1.5^{\circ} \mathrm{C}$ higher on average than the measured temperature without the shading screen extended over the crop.

Figure 2C compares measured with predicted temperature on plants under whitewashed glass without the shading screen. The maximum measured temperature was $\approx 34{ }^{\circ} \mathrm{C}$, a value $4{ }^{\circ} \mathrm{C}$ lower than that under clear glass at the same time. The predicted temperatures are similar to measured temperatures except from about sunrise to 0900 HR. During this period, there was a brief, small drop followed by an increase in temperature. The model did not predict this brief temperature drop, but did predict the rise in temperature but with a greater magnitude than that measured.

Figure 2D compares measured with predicted temperature on plants under whitewashed glass and with the shading screen. The shading screen was pulled from 0930 to 1900 HR. Shortwave radiation inside the greenhouse was very low because of the combination of whitewash and the shading screen. The measured and predicted shoot-tip temperatures were close to dry-bulb temperature the whole day.

Overall, the predicted shoot-tip temperatures qualitatively agreed well with the measured temperatures under the light and temperature conditions that are present in commercial greenhouses. The model is more effective than measured dry bulb temperature at predicting plant shoot-tip temperature when solar radiation is moderate to high and shade curtains are not deployed (Fig. 2A, C). Therefore, predicted shoot-tip temperature could be used in an environmental control computer to determine when shade curtains should be deployed based on some maximum plant temperature, rather than some arbitrary light level that may result in premature or delayed deployment.

VALIDATION. Validation of the model comparing agreement between the predicted and measured temperatures was evaluated quantitatively. The difference between the predicted temperature and the measured temperature was determined using all data in July and August (8547 observations). A graph of this object function is shown in Fig. 3; the horizontal axis is the difference between 


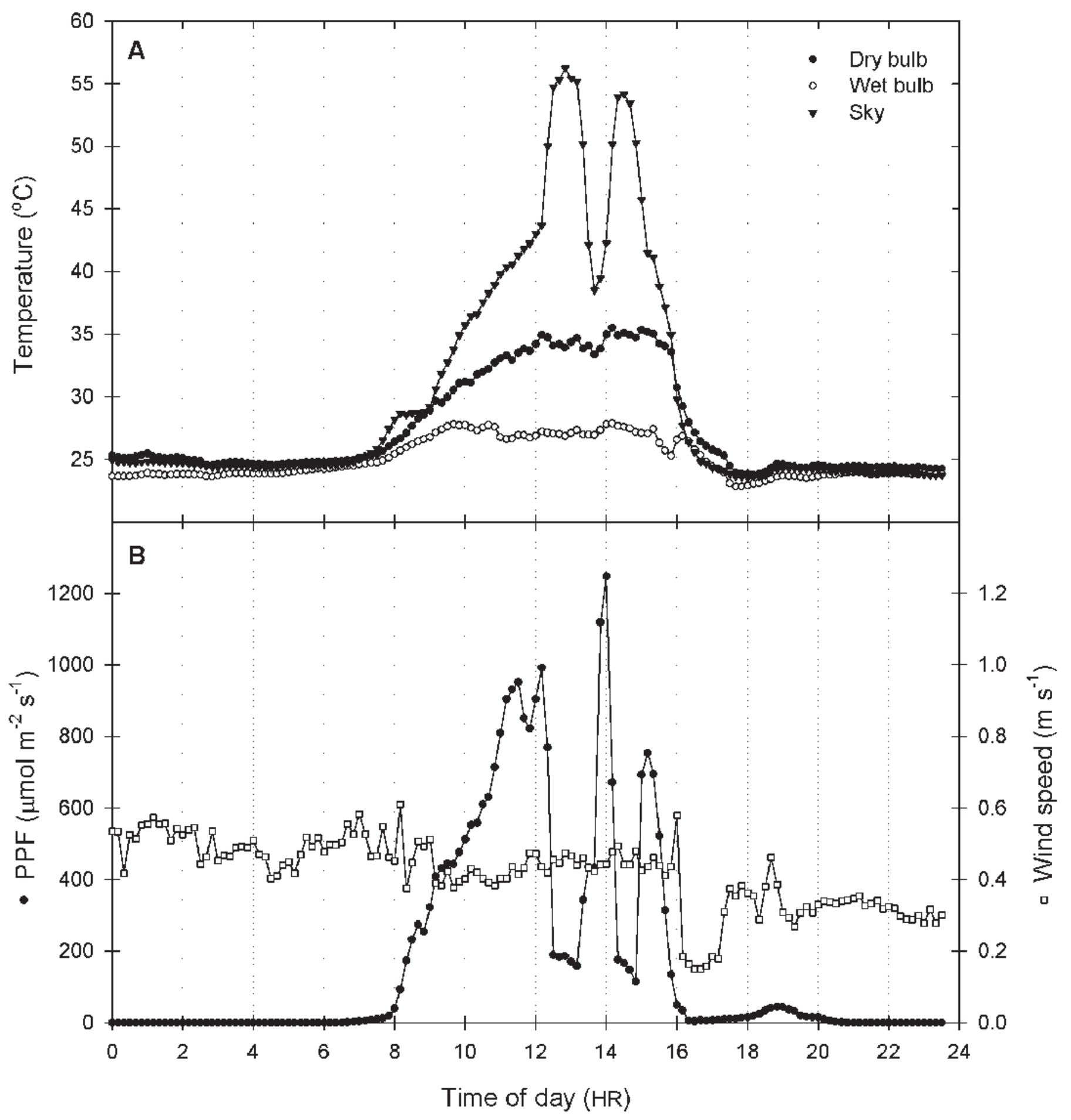

Fig. 1. Dry-bulb, wet-bulb, and sky temperature; transmitted photosynthetic photo flux $(P P F)$; and air velocity recorded inside a commercial glass greenhouse in Apopka, Florida (lat. $28^{\circ} \mathrm{N}$ ) on a typical summer day (6 July 1998). The peaks in sky temperature and dips in shortwave radiation coincide with when shade curtains were deployed over the crop canopy. 


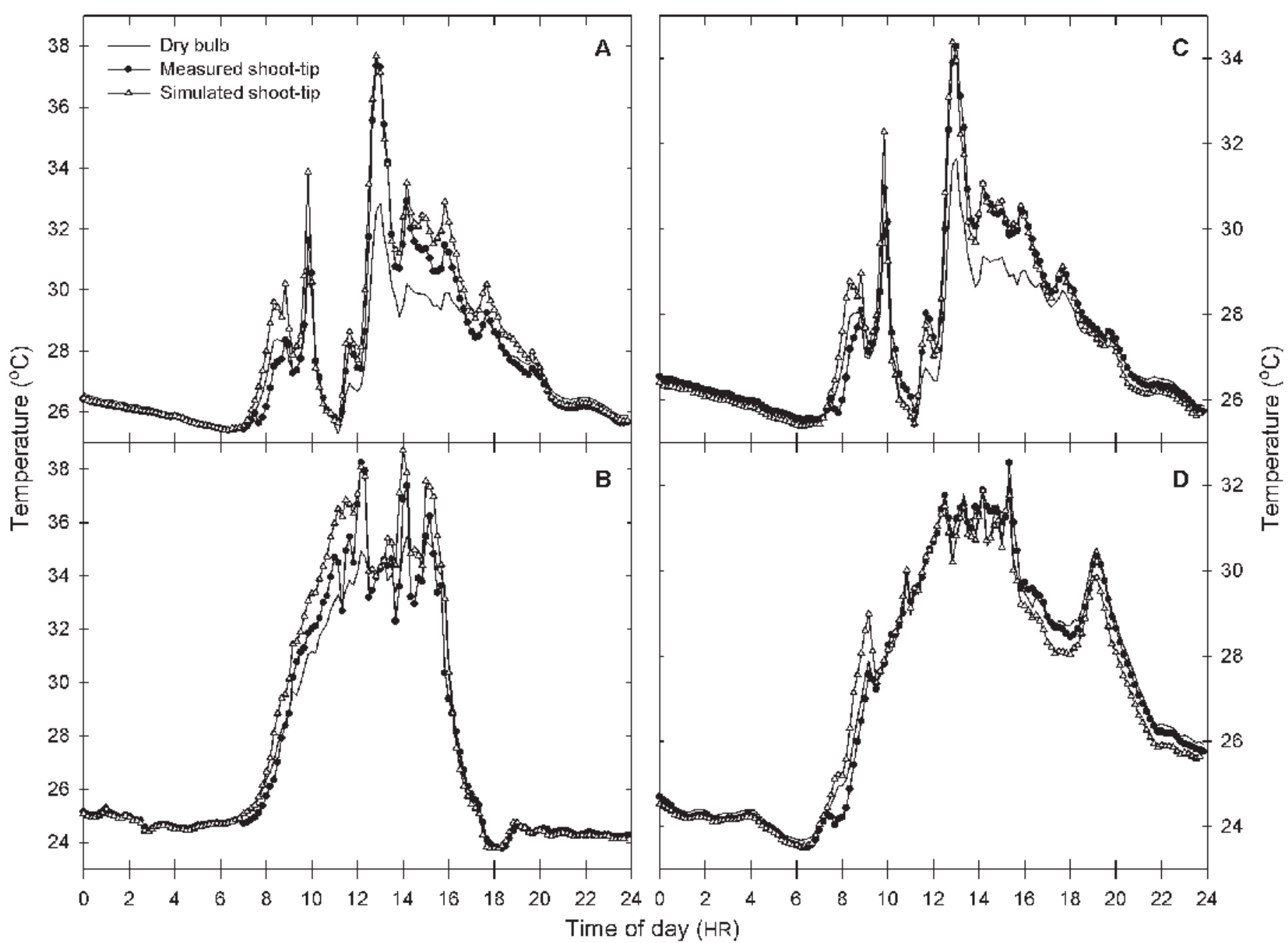

Fig. 2. Actual and simulated poinsettia shoot-tip temperature time-series data sets on a typical summer day in a commercial glass greenhouse with four different light environments: clear glass without a retractable curtain (A); clear glass with a retractable shade curtain [reducing light transmission by $85 \%$; (B)]; whitewashed glass (reducing light transmission by $\approx 50 \%$ ) without a curtain $(\mathbf{B})$; and whitewashed glass with a retractable curtain (D).

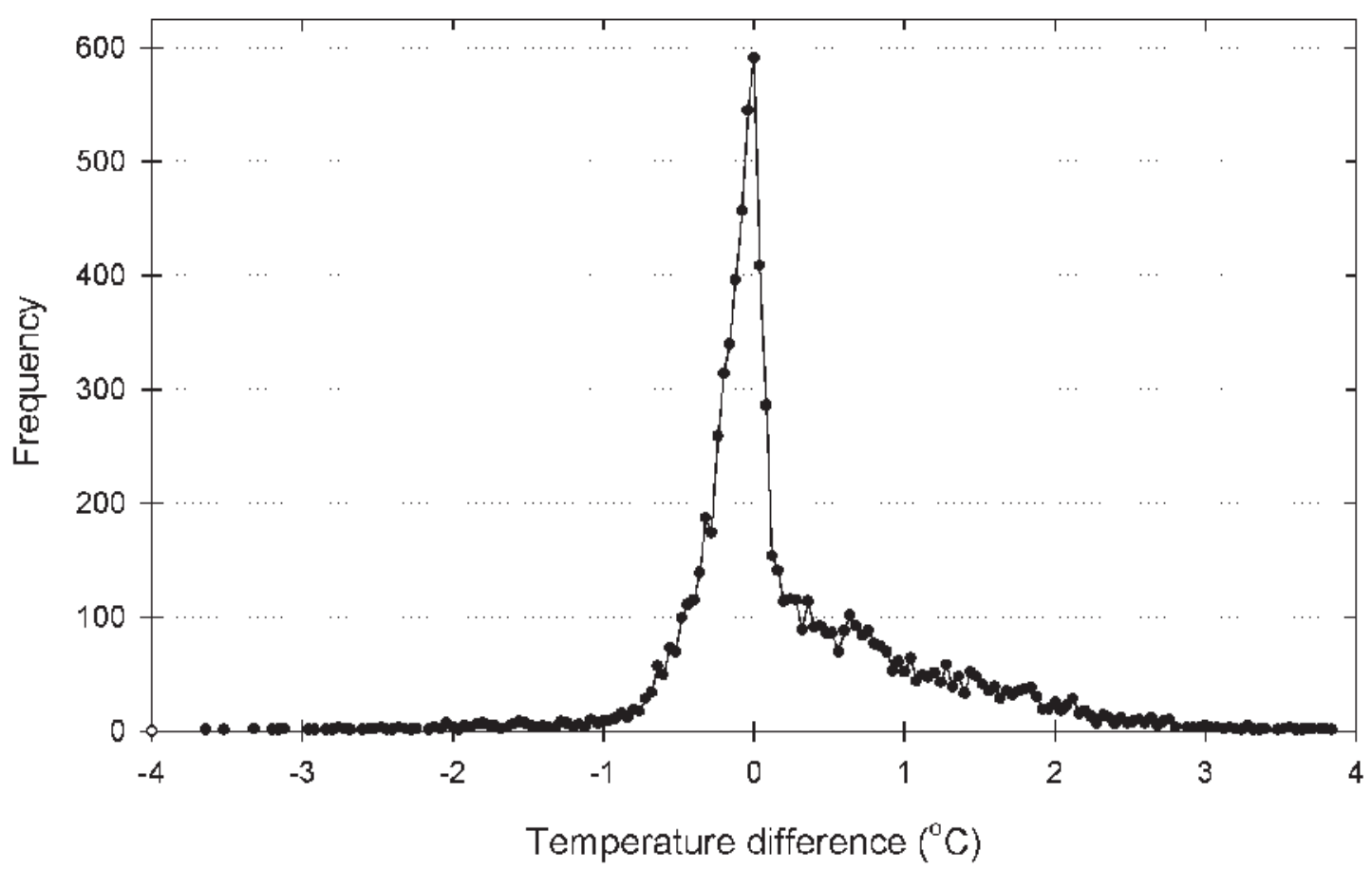

Fig. 3. Frequency of the difference between simulated plant shoot-tip temperature $\left(\mathrm{T}_{\mathrm{PSIM}}\right)$ and measured plant shoot-tip temperature $\left(\mathrm{T}_{\mathrm{PMES}}\right)$ of poinsettia using data from 2 months (8547 observations). Plants were grown under four different light environments in a commercial glass greenhouse. 
the predicted and measured temperature, and the vertical axis is the frequency. The distribution of $\mathrm{T}_{\text {PSIM }} \mathrm{T}_{\text {PMES }}$ has a single peak shape and the peak is at zero. The data points were not normally distributed about the mean, and a small bias existed when the predicted values exceeded the actual values. These values primarily reflect the predictions of plant temperature during the first two hours of the morning when predicted temperature exceeded measured temperature (Fig. 2). One possible explanation of this deviation is that the model assumes a constant value for shoot-tip cuticle resistance $\left(r_{C}\right)$ in Eq. [16]. If $r_{C}$ decreases as light increases at sunrise due to greater stomatal aperture (assuming stomata are functional), transpiration would be greater than that estimated, and shoot-tip temperature would be lower than predicted at this time of day. Still, the standard deviation was only $0.798^{\circ} \mathrm{C}$, and $>84 \%$ of the total predicted temperatures differed less than $1{ }^{\circ} \mathrm{C}$ compared with the measured temperature.

EVALUATION OF THE EFFECT OF GREENHOUSE ENVIRONMENTAL FACTORS ON SHOOT-TIP TEMPERATURE. One of the useful advan- tages of a simulation study is that one environmental factor can be varied arbitrarily independent of other variables. In a commercial greenhouse, when one environmental factor is changed, other factors also change. For example, when solar radiation is changed, the sky temperature and dry-bulb temperature also change. We selected one data set for use as standard conditions for simulation. These data were collected under clear glass at 1250 HR on July 10 and are listed in Table 3 (simulation data). Figure 4 shows the predicted effect of changing a single environmental factor (with the four other environmental factors held constant) upon the shoot-tip temperature by using this data set. The ranges of predictions were based on the range of environmental conditions measured on that date.

The effect of changing dry-bulb, wet-bulb, and sky temperature was simulated. The simulated shoot-tip temperature increased linearly $0.74{ }^{\circ} \mathrm{C}$ for each increase of $1^{\circ} \mathrm{C}$ in dry-bulb temperature as the latter increased from 28 to $42^{\circ} \mathrm{C}$. Increasing wet-bulb temperature also increased shoot-tip temperature; however, the rate was

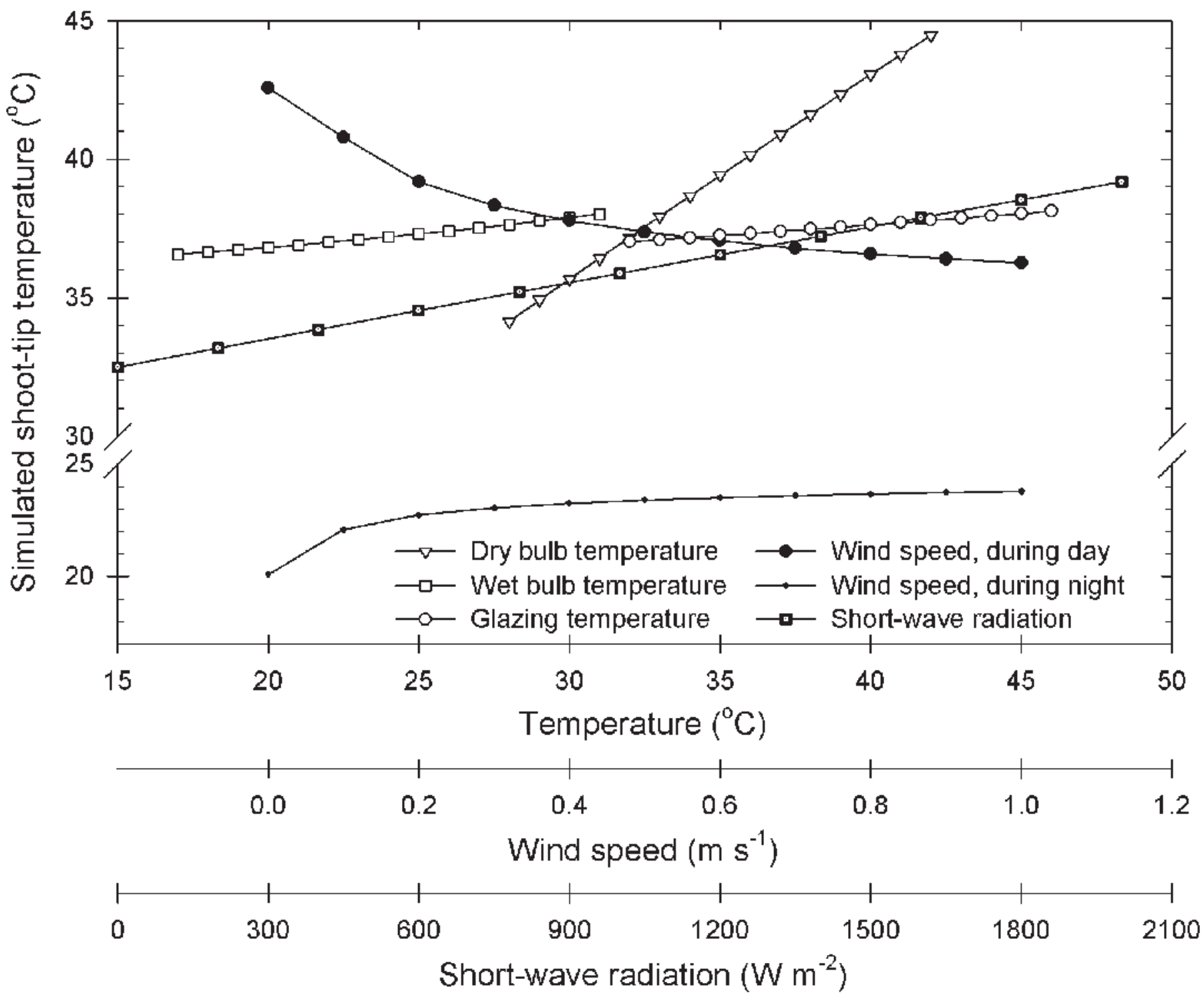

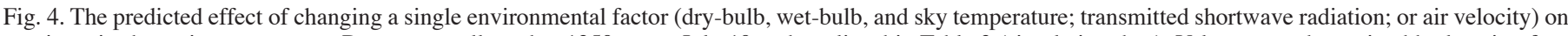

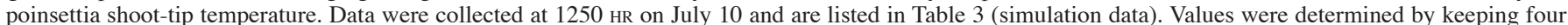

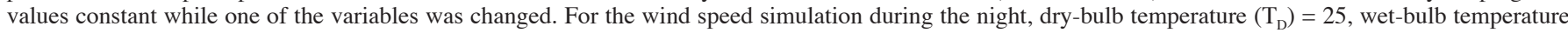
$\left(T_{W}\right)=22$, sky temperature $\left(T_{S}\right)=0$, and short-wave radiation $(S W)=0$. 
lower than that of the dry-bulb, increasing only $0.10^{\circ} \mathrm{C}$ for each 1 ${ }^{\circ} \mathrm{C}$ increase in wet-bulb temperature. The effect of increasing the sky temperature resulted in an increase of $0.08{ }^{\circ} \mathrm{C}$ for each $1{ }^{\circ} \mathrm{C}$ increase in sky temperature. These simulation results demonstrate that the dry-bulb temperature has the greatest impact on shoot-tip temperature among three temperature factors studied. This is not unexpected, since the standard environmental factor manipulated by greenhouse growers to hasten or retard plant development is dry bulb temperature, not wet bulb or sky temperature.

The magnitude of the daily changes in wet-bulb, dry-bulb, and sky temperature varied considerably. For example, the wetbulb, dry-bulb, and sky temperature varied by $\approx 5,10$, and $30{ }^{\circ} \mathrm{C}$, respectively, on a typical summer day (Fig. 1). Thus, although a $1{ }^{\circ} \mathrm{C}$ increase in the wet-bulb or sky temperature increased plant shoot tip temperature similarly $\left(\approx 0.1{ }^{\circ} \mathrm{C}\right)$, the sky temperature had a greater absolute effect on shoot-tip temperature since the magnitude of the increase $\left(30^{\circ} \mathrm{C}\right)$ was greater than that of the wet-bulb temperature increase $\left(5^{\circ} \mathrm{C}\right)$ during the day. In this instance, sky temperature was predicted to increase the shoot-tip temperature by up to $2.4{ }^{\circ} \mathrm{C}$, which is much greater than the maximum predicted increase in shoot-tip temperature from the increase in wet-bulb temperature $\left(0.5^{\circ} \mathrm{C}\right)$.

Shortwave radiation is also one of the major factors that significantly influence shoot-tip temperature. As solar radiation increased, the simulated shoot-tip temperature increased linearly $0.67{ }^{\circ} \mathrm{C}$ per $100 \mathrm{~W} \cdot \mathrm{m}^{-2}$ (Fig. 4). Thus, a change in shortwave radiation of $500 \mathrm{~W} \cdot \mathrm{m}^{-2}$ leads to a shoot-tip temperature change of $3.3{ }^{\circ} \mathrm{C}$ according to the simulation model. To control shoottip temperature as natural solar radiation changes requires either modulation of internal radiation by pulling of a shading screen (negating the increase in radiation), increasing air velocity, or decreasing dry bulb temperature. Decreasing greenhouse dry bulb temperature when radiation becomes high is only feasible when the outdoor dry bulb temperature is substantially lower than the desired interior dry bulb temperature. Although pulling the screen may increase sky temperature, it only has a small effect on shoot-tip temperature and thus will affect shoot-tip temperature very little (Fig. 4).

Shoot-tip temperature was predicted to decrease (become closer to dry-bulb temperature) in a nonlinear fashion as the air velocity increased during the day (Fig. 4). The effect of increasing air velocity was greatest in the region of the low air velocities. In the simulated condition here, the shoot-tip temperature decreased $5^{\circ} \mathrm{C}$ when the air velocity increased from 0 to $0.5 \mathrm{~m} \cdot \mathrm{s}^{-1}$. However, this decrease is applicable only under conditions in which the shoottip temperature exceeds dry-bulb temperature, and the reverse applies in other situations. For example, Fig. 4 also shows how simulated shoot-tip temperature changes during the night as air velocity is varied from 0 to $1 \mathrm{~m} \cdot \mathrm{s}^{-1}$ when dry-bulb temperature is $25^{\circ} \mathrm{C}$, wet-bulb temperature is $22^{\circ} \mathrm{C}$, sky temperature is $5^{\circ} \mathrm{C}$, and light intensity is $0 \mu \mathrm{mol} \cdot \mathrm{m}^{-2} \cdot \mathrm{s}^{-1}$. The shoot-tip temperature increases as the air velocity increases in this situation because air velocity directly affects the boundary layer thickness around the shoot tip (Bejan, 1984). Increasing the air velocity decreases the boundary layer thickness and therefore decreases the resistance of convective heat transfer between the shoot tip and the ambient air. Therefore, estimating the shoot-tip temperature precisely under low air velocities is important because the shoot-tip temperature can differ greatly from the dry-bulb temperature under this condition.

The simulation model was also used to study the effects of nighttime conditions on shoot-tip temperature. In winter, sky temperature of greenhouses becomes low because outside temperature during the night can be very low in the northern latitudes (e.g., northern parts of the United States) and in very dry climates. The air velocity is very low during the night without any active circulation, resulting in a thick boundary layer. Because of radiant cooling to the sky, the shoot-tip temperature can drop below air temperature. In a simulation where $\mathrm{T}_{\mathrm{D}}=25, \mathrm{~T}_{\mathrm{W}}=22, \mathrm{~T}_{\mathrm{S}}=0, \mathrm{SW}$ $=0$, and $\mathrm{V}=0.05$, shoot-tip temperature was calculated at $4.2^{\circ} \mathrm{C}$ lower than the greenhouse dry-bulb temperature. Increasing $\mathrm{T}_{\mathrm{S}}$ to $10{ }^{\circ} \mathrm{C}$ still resulted in a shoot-tip temperature approximately $3{ }^{\circ} \mathrm{C}$ lower than the greenhouse dry-bulb temperature.

Faust and Heins (1998) reported similar results in vinca by means of experiment and simulation: shoot-tip temperature was as much as $5^{\circ} \mathrm{C}$ below air temperature when the sky material temperature was $16^{\circ} \mathrm{C}$ below air temperature. To increase horizontal air flow, many greenhouses have installed small fans to increase air temperature uniformity throughout the greenhouse. In most situations, the active air flow that increases plant temperature during night is a benefit, as it hastens plant development and thus reduces crop timing.

The poinsettia shoot-tip temperature model developed in this paper is much more theoretical compared to the Faust and Heins (1998) shoot-tip model on vinca. For example, the terms in the energy balance equation (short-wave radiation, long-wave radiation, convection, and transpiration) were all calculated based on equations analyzed in the field of thermodynamics and heat transfer, and although the Faust and Heins model used short-wave and long-wave radiation terms based on theoretical calculations, calculation of the other energy modes including convection and transpiration was not theoretical.

Computers are commonly employed in greenhouse climate control (Albright, 1990; Kamp and Timmerman, 1996; Marcelis and De Konig, 1995). Since the model developed in this simulation model accurately predicts shoot-tip temperature, the simulated temperature from this model could be used as a feedback signal in a computer control system and thereby control shoot-tip temperature via climate control. Managing a greenhouse environment based on shoot-tip temperature has the potential to improve the accuracy of controlling crop timing.

\section{Literature Cited}

Albright, L.D. 1990. Environment control for animal and plants. Amer. So. Agr. Eng., St. Joseph, Mich.

Bejan, A. 1984. Convection heat transfer. Wiley Interscience, New York.

Ben-Haj-Salah, H. and F. Tardieu. 1995. Temperature affects leaf expansion rate of maize without change in spatial distribution of cell length. Analysis of the coordination between cell division and cell expansion. Plant Physiol. 109:861-870.

Boulard, T. and B. Draoui. 1996. Calibration and validation of a greenhouse climate control model. Acta Hort. 406:49-61.

Dole, J.M. and H.F. Wilkins. 1999. Floriculture: principles and species. Prentice-Hall, Upper Saddle River, N.J.

Faust, E.J. and R.D. Heins. 1998. Modeling shoot-tip temperature in the greenhouse environment. J. Amer. Soc. Hort. Sci. 123:208-214.

Gallagher, J.N. and P.V. Biscoe. 1979. Field studies of cereal leaf growth: 3. Barley leaf (Hordeum distichum cv. Proctor) extension in relation to temperature, irradiance and water potential. J. Expt. Bot. 30:645-656.

Gregory, P.J. 1983. Response to temperature in a stand of pearl millet (Pennisetum typhoides): 3. Root development. J. Expt. Bot. 34: 744-756.

Hanan, J.J. 1998. Greenhouses: Advanced technology for protected 
horticulture. CRC Press, New York.

Holman, J.P. 1997. Heat transfer. $8^{\text {th }}$ ed. McGraw-Hill, New York.

Jones, H.G. 1994. Plants and microclimate: A quantitative approach to environmental plant physiology. Cambridge Univ. Press, New York.

Kamp,P.G.H. and G.J. Timmerman. 1996. Computerized environmental control in greenhouse. IPC-Plant, Ede, The Netherlands.

Kempkes, F.L.K., N.J. Van de Braak, and J.C. Bakker. 2000. Effect of heating system position on vertical distribution of crop temperature and transpiration in greenhouse tomatoes. J. Agr. Eng. Res. 75:57-64.

Kreith, F. and J.F. Kreider. 1978. Principles of solar engineering. McGraw-Hill, New York.

Marcelis, L.F.M. and A.N.M. De Konig. 1995. Biomass partitioning in plants, p. 84-92. In: J.C. Bakker, G.P.A. Bot, A. Challa, and N.J. Van de Braak (eds.). In: Greenhouse climate control: An integrated approach. Wageningen Press, Wageningen, The Netherlands.

Monteith, J.L. and M. Unsworth. 1990. Principles of environmental physics. $2^{\text {nd }}$ ed. Arnold, London.

Nishina, H., Y. Hashimoto, and A. Morimoto. 1996. Identification and control of air temperature in greenhouse systems. Acta Hort. 406: 29-33.

Ong, C.K. 1983. Response to temperature in a stand of pearl millet (Pennisetum typhoides): 4. Extension of individual leaves. J. Expt.
Bot. 34:1731-1739.

Pitts, D.R. 1977. Theory and problem of heat transfer. McGraw-Hill, New York, N.Y.

Shimizu, H. and R.D. Heins. 2000. Development for measuring method for cuticle resistance of plant shoot tip (in Japanese with English summary). J. Soc. High Technol. Agr. 12(3):155-159.

Tardieu, F., M. Reymond, P. Hamard, C. Granier, and B. Muller. 2000. Spatial distributions of expansion rate, cell division rate and cell size in maize leaves: A synthesis of the effects of soil water status, evaporative demand and temperature. J. Expt. Bot. 51:1505-1514.

Thimijan, R.W. and R.D. Heins. 1983. Photometric, radiometric, and quantum light units for measure: A review of procedures for interconversion. HortScience 18(6):818-822.

United States Department of Agriculture. 2002. Floriculture crops 2001 summary. http://usda.mannlib.cornell.edu/reports/nassr/other/zfcbb/floran02.pdf.

Van Stranten, G. and H. Challa. 1995. Greenhouse climate control systems. In: J.C. Bakker, G.P.A. Bot, H. Challa, and N.J. Van de Braak (eds.). Greenhouse climate control: An integrated approach. Wageningen Press, Wageningen, The Netherlands.

Wilhelm, W.W., H. Bouzerzour, and J.F. Power. 1989. Soil disturbanceresidue management effect on winter wheat growth and yield. Agron. J. 81:581-588. 